\title{
THE ROLE OF THE WORLD INSURANCE MARKET INFRASTRUCTURE
}

\author{
Antonina SHOLOIKO ${ }^{1}$ \\ Taras Shevchenko National University of Kyiv, Ukraine
}

\begin{abstract}
The purpose is to define a role and significance of elements of the world insurance market infrastructure. Tasks of the study are the next: to consider the dynamics of development of the world insurance market from 2012 to 2016; to define groups of elements of the world insurance market infrastructure; to characterize elements of the world insurance market infrastructure. Methodology. These tasks are done because of using such methods as: grouping of elements of the world insurance market infrastructure; a collection of information about elements of the world insurance market infrastructure; generalization to define role and significance of elements of the world insurance market infrastructure. Results. World insurance premiums were increasing and decreasing from 2012 to 2016 and did not exceed 6.3\% of Gross Domestic Product. Lots of factors influence global insurance premium volume as an indicator of the development of world insurance market. One of them is an activity of the elements of the world insurance market infrastructure. It is necessary to divide them into some groups: A) International insurance associations (associations of organizations connected with insurance but members of such associations do not provide insurance services - International Association of Insurance Supervisors, International Association of Insurance Fraud Agencies, Global Federation of Insurance Associations, International Insurance Foundation; B) International associations of insurers (includes associations of insurers and other organizations in a certain area of insurance - International Association of Deposit Insurers, International Union of Credit and Investment Insurers, International Association of Agricultural Production Insurers, International Group of P\&I Clubs, International Union of Aerospace Insurers, International Union of Marine Insurance, International Association of Engineering Insurers); C) International associations of insurance experts (associations of insurance experts that serve providing of insurance services - International Association of Insurance Professionals, International Actuarial Association, International Association of Average Adjusters). Value. This study has shown that all groups of elements of world insurance market infrastructure play a significant role in the development of the insurance industry because they set such tasks as: facilitate to the global stability, safety, efficiency through the collaboration with national governments and providing members of associations with information, education, consultation and other services. More research is required to consider an activity of elements of European, American, and Asian insurance market infrastructure as leading in the world.
\end{abstract}

Key words: world insurance market, infrastructure, international insurance associations, international associations of insurers, international associations of insurance experts.

JEL Classification: G22, H54

\section{Introduction}

Different elements of infrastructure have a considerable impact on the development of the world insurance market and national markets. The various elements of insurance market infrastructure have received an increased interest in publications of G.B. Ermolaev (2011), R. Lee (2011), T.A. Rotova and S.V. Zaychuk (2014), O.V. Vasiliev (2013) and others. But these studies have tended to focus on nature of insurance market infrastructure and national elements of it rather than on elements of world insurance market infrastructure.
Therefore this paper attempts to define a role and significance of elements of the world insurance market infrastructure.

Tasks of the study are the next:

- to consider the dynamics of development of the world insurance market from 2012 to 2016;

- to define groups of elements of the world insurance market infrastructure;

- to characterize elements of the world insurance market infrastructure.

These tasks were done because of using such methods as: grouping of elements of the world insurance market

Corresponding author:

${ }^{1}$ Department of Insurance of Banking and Risk Management, Taras Shevchenko National University of Kyiv.

E-mail: sholoiko@ukr.net 
infrastructure; a collection of information about elements of the world insurance market infrastructure; generalization to define role and significance of elements of the world insurance market infrastructure.

Information for this study was collected from Swiss Re Institute's publications and official web sites of elements of the world insurance market infrastructure.

\section{The world insurance market}

World insurance premiums were increasing and decreasing from 2012 to 2016 and did not exceed 6.3\% in Gross Domestic Product (GDP). The dynamics of world insurance premiums and its share in GDP from 2012 to 2016 is presented in Table 1 .

Lots of factors influence global insurance premium volume as an indicator of the development of world insurance market. One of them is an activity of the elements of the world insurance market infrastructure. It is necessary to divide them into some groups:

A) International insurance associations such as International Association of Insurance Supervisors (IAIS), International Association of Insurance Fraud Agencies (IAIFA), Global Federation of Insurance Associations (GFIA), International Insurance Foundation (IIF);

B) International associations of insurers (International Association of Deposit Insurers (IADI), International Union of Credit and Investment Insurers (IUCII), International Association of Agricultural Production Insurers (AIAG), International Group of P\&I Clubs (IG P\&I), International Union of Aerospace Insurers (IUAI), International Union of Marine Insurance (IUMI), International Association of Engineering Insurers (IMIA));

C) International associations of insurance experts (International Association of Insurance Professionals (IAIP), International Actuarial Association (IAA), International Association of Average Adjusters (IAAA) and others).

\section{Characteristic of elements of the world insurance market infrastructure}

The first group of the elements of the world insurance market infrastructure is International insurance associations. This group of elements includes associations of organizations connected with insurance but members of such associations do not provide insurance services (Table 2).

The information from Table 2 allows making a conclusion that international insurance associations act mainly on the world level and aims at global stability, safety, and efficiency of the insurance industry.

The second group of the elements of the world insurance market infrastructure is International

Table 1

The dynamics of world insurance premiums and its share in GDP from 2012 to 2016

\begin{tabular}{|l|c|c|c|c|c|c|c|c|c|}
\hline \multicolumn{1}{|c|}{ Indicator } & 2012 & 2013 & 2014 & 2015 & 2016 & \multicolumn{4}{|c|}{ Tendencies } \\
\cline { 5 - 10 } & & & & & & $\begin{array}{c}2013 / \\
2012\end{array}$ & $\begin{array}{c}2014 / \\
2013\end{array}$ & $\begin{array}{c}2015 / \\
2014\end{array}$ & $\begin{array}{c}2016 / \\
2015\end{array}$ \\
\hline Life insurance premium volume, bn USD & 2630.27 & 2545.00 & 2655.59 & 2546.94 & 2617.02 & $\downarrow$ & $\uparrow$ & $\downarrow$ & $\uparrow$ \\
\hline Non-life insurance premium volume, bn USD & 1968.68 & 2048.6 & 2099.12 & 2050.74 & 2115.17 & $\uparrow$ & $\uparrow$ & $\downarrow$ & $\uparrow$ \\
\hline Total premium volume, bn USD & 4598.95 & 4593.6 & 4754.71 & 4597.68 & 4732.19 & $\downarrow$ & $\uparrow$ & $\downarrow$ & $\uparrow$ \\
\hline $\begin{array}{l}\text { Share of premiums in GDP (insurance } \\
\text { penetration), \% }\end{array}$ & 6.5 & 6.28 & 6.17 & 6.23 & 6.28 & $\downarrow$ & $\downarrow$ & $\uparrow$ & $\uparrow$ \\
\hline
\end{tabular}

Source: compiled by the author based on Swiss Re Institute's data

Table 2

Characteristic of international insurance associations

\begin{tabular}{|l|l|}
\hline \multicolumn{1}{|c|}{ Association } & \multicolumn{1}{c|}{ Characteristic } \\
\hline $\begin{array}{l}\text { International Association } \\
\text { of Insurance Supervisors } \\
\text { (established in 1994) }\end{array}$ & $\begin{array}{l}\text { Unites insurance supervisors and regulators from } 140 \text { countries on a voluntary base. The mission of the } \\
\text { IAIS is to promote effective and globally consistent supervision of the insurance industry in order to } \\
\text { develop and maintain fair, safe and stable insurance markets for the benefit and protection of policyholders } \\
\text { and to contribute to global financial stability }\end{array}$ \\
\hline $\begin{array}{l}\text { International Association of } \\
\text { Insurance Fraud Agencies } \\
\text { (established in 1987) }\end{array}$ & $\begin{array}{l}\text { Coordinates the efforts, training, and education of law enforcement agencies, government bodies, and the } \\
\text { insurance industry to more effectively prevent and combat insurance fraud worldwide }\end{array}$ \\
\hline $\begin{array}{l}\text { Global Federation of } \\
\text { Insurance Associations } \\
\text { (established in 2012) }\end{array}$ & $\begin{array}{l}\text { Represent national and regional insurance associations that serve the general interests of life, health, general } \\
\text { insurance and reinsurance companies and make representations to national governments, international } \\
\text { regulators, and others on their behalf }\end{array}$ \\
\hline $\begin{array}{l}\text { International Insurance } \\
\text { Foundation }\end{array}$ & $\begin{array}{l}\text { Brings together all parties, public and private sectors and is an independent centre for research and } \\
\text { education. It focuses on global standards for insurance markets. Sound and robust insurance markets } \\
\text { contribute to economic growth by reducing vulnerability and encouraging risk management }\end{array}$ \\
\hline
\end{tabular}

Source: compiled by the author based on information from: https://www.iaisweb.org/page/about-the-iai; http://www.naic.org/store/free/FRD-OP. pdf; http://gfiainsurance.org/en/About-us/Overview/; https://iifdc.org/?page_id=59 
Table 3

\section{Characteristic of International associations of insurers}

\begin{tabular}{|c|c|}
\hline Association/Union & Characteristic \\
\hline $\begin{array}{l}\text { International Association of } \\
\text { Deposit Insurers (established } \\
\text { in 2002) }\end{array}$ & $\begin{array}{l}\text { Includes } 84 \text { Member organizations (deposit insurance organizations), } 8 \text { Associates (other safety-net organizations } \\
\text { from jurisdictions that have developed or are considering developing a deposit insurance system), and } 14 \text { Partners } \\
\text { (organizations that have entered into a cooperative arrangement with IADI in order to pursue IADI's goals) }\end{array}$ \\
\hline $\begin{array}{l}\text { International Union of Credit } \\
\text { and Investment Insurers } \\
\text { (founded in 1934) }\end{array}$ & $\begin{array}{l}\text { International not-for-profit trade association, representing the global export credit and investment insurance } \\
\text { industry that includes } 84 \text { members (government-backed export credit agencies, private credit and political risk } \\
\text { insurers and multilateral institutions from across the globe who provide insurance products, guarantees) }\end{array}$ \\
\hline $\begin{array}{l}\text { International Association } \\
\text { of Agricultural Production } \\
\text { Insurers (established in 1951) }\end{array}$ & $\begin{array}{l}\text { Founding members, with representatives from France, Germany, Italy, the Netherlands, Sweden, and } \\
\text { Switzerland, set themselves the objectives of improving and expanding coverage and hail insurers' services } \\
\text { through the exchange of information, experience, and statistics }\end{array}$ \\
\hline $\begin{array}{l}\text { International Group of P\&I } \\
\text { Clubs (established in 1899) }\end{array}$ & $\begin{array}{l}\text { The thirteen principal underwriting associations, which comprise the International Group, between them } \\
\text { provide liability cover (protection and indemnity) for approximately } 90 \% \text { of the world's ocean-going tonnage. } \\
\text { Each Group Club is an independent, non-profit making mutual insurance association, providing cover for its } \\
\text { ship-owner and charterer members against third party liabilities relating to the use and operation of ships }\end{array}$ \\
\hline $\begin{array}{l}\text { International Union } \\
\text { of Aerospace Insurers } \\
\text { (established in 1934) }\end{array}$ & $\begin{array}{l}\text { With Membership standing at } 77 \text { entities, comprising insurers, reinsurers and associations drawn from } 28 \\
\text { different countries, was estimated that at about } 90 \% \text { of the worldwide aerospace insurance cover is written } \\
\text { by members of IUAI who between them provide coverage for every aspect of aerospace business }\end{array}$ \\
\hline $\begin{array}{l}\text { International Union of } \\
\text { Marine Insurance (established } \\
\text { in 1874) }\end{array}$ & $\begin{array}{l}\text { Represents national and international marine insurers and considers issues of interest to the worldwide } \\
\text { marine insurance industry. Members of IUMI are dedicated to maintaining and expanding global trade } \\
\text { focusing both on developed and emerging markets }\end{array}$ \\
\hline $\begin{array}{l}\text { International Association } \\
\text { of Engineering Insurers } \\
\text { (established in 1968) }\end{array}$ & $\begin{array}{l}\text { Its Members are national Insurance Associations around the world, individual Insurance Companies, } \\
\text { Reinsurers and various Associate Members (Loss Adjusters, Consultants, Brokers) all dealing within the } \\
\text { Engineering Insurance market }\end{array}$ \\
\hline
\end{tabular}

Source: compiled by the author based on information from: http://wwwiadi.org/en/about-iadi/organisation/; https://www.berneunion.org/Stub/ Display/8; http://www.aiag-iahi.org/en/about-us/; https://iuai.org/IUAI/About/Public/About/About.aspx?hkey=d8d8da15-56bb-4d94-8689e2a2803d706d; https://www.igpandi.org/about; https://iumi.com/about/introducing-iumi; https://www.imia.com/the-organisation/

Table 4

Ukraine in Top 10 Countries by claims paid within MLT and INV insurance in 2016-2016

\begin{tabular}{|c|l|c|c|}
\hline \multicolumn{2}{|c|}{ Indicator } & 2015 & 2016 \\
\hline \multirow{3}{*}{$\begin{array}{c}\text { MLT Claims } \\
\text { Paid }\end{array}$} & Ukraine, USD Million & 168 & 228 \\
\cline { 2 - 4 } & Total, USD Million & 3252 & 3008 \\
\cline { 2 - 4 } & Share of Ukraine in total, \% & 5,17 & 7,58 \\
\hline \multirow{2}{*}{$\begin{array}{c}\text { INV Claims } \\
\text { Paid }\end{array}$} & Ukraine, USD Million & 8 & 17 \\
\cline { 2 - 4 } & Total, USD Million & 150 & 300 \\
\cline { 2 - 4 } & Share of Ukraine in total, \% & 5,33 & 5,67 \\
\hline
\end{tabular}

Source: compiled by the author based on information from: http://cdn.berneunion.org/assets/Images/Berne-Union-2016-YearEnd-Statistics.pdf

associations of insurers. This group of elements includes associations of insurers and other organizations in a certain area of insurance (Table 3).

The most of the International associations of insurers from Table 3 were established in XIX - XX centuries and have a long history, lots of experience and traditions in a certain segment of world insurance market. It is necessary to mention that Joint Stock Company "State Export-Import Bank of Ukraine" (Ukreximbank) is a member of such an element of the world insurance market infrastructure as International Union of Credit and Investment Insurers. Ukraine belonged to Top 10 countries by claims paid within medium/long term export credit insurance and lending (MLT) and investment insurance (INV) in 20152016 (Table 4).

Increasing of the claims paid is not a positive tendency and points to instability and unreliability in interaction with foreign counteragents.

The third group of the elements of the world insurance market infrastructure is international associations of insurance experts. This group of elements includes associations of insurance experts that serve the provision of insurance services (Table 5).

Table 5

Characteristic of international associations of insurance experts

\begin{tabular}{|l|l|}
\hline \multicolumn{1}{|c|}{ Association } & \multicolumn{1}{c|}{ Characteristic } \\
\hline $\begin{array}{l}\text { International Association of } \\
\text { Insurance Professionals (established } \\
\text { in 1938) }\end{array}$ & $\begin{array}{l}\text { Professional association open to individuals in the insurance and risk management industries. } \\
\text { IAIP is best known for providing insurance education, leadership development and networking } \\
\text { opportunities to its members }\end{array}$ \\
\hline $\begin{array}{l}\text { International Actuarial Association } \\
\text { (founded in 1895) }\end{array}$ & $\begin{array}{l}\text { It is the worldwide association of professional actuarial associations, with a number of special interest sections } \\
\text { for individual actuaries. The IAA exists to encourage the development of a global profession, acknowledged } \\
\text { as technically competent and professionally reliable, which will ensure that the public interest is served }\end{array}$ \\
\hline $\begin{array}{l}\text { International Association of Average } \\
\text { Adjusters (established in 1961) }\end{array}$ & $\begin{array}{l}\text { Provides Average Adjusting and Claims Consultancy services in the marine environment. The members of } \\
\text { this association provide worldwide solutions with sound advice and well-reasoned opinions }\end{array}$ \\
\hline
\end{tabular}

Source: compiled by the author based on information from: http://www.internationalinsuranceprofessionals.org/; http://www.actuaries.org/index. cfm? $L A N G=E N \& D S P=A B O U T \& A C T=I N D E X ;$ http://amdadjusters.org/bringing-solutions-to-problems/ 
The information from Table 5 gives a possibility to generalize that the main goal of international associations of insurance experts is to develop a certain profession connected with insurance and provide a support to members of such associations.

It is necessary to highlight that Society of Actuaries of Ukraine is an Associate Member of International Actuarial Association since 2001.

\section{Conclusions}

In this investigation, the aim was to characterize the role and significance of such groups of elements of world insurance market infrastructure: international insurance associations, international associations of insurers, and international associations of insurance experts. This study has shown that all groups of elements of world insurance market infrastructure play a significant role in the development of the insurance industry because they set such tasks as: facilitate to the global stability, safety, efficiency through collaboration with national governments and providing members of associations by information, education, consultation and other services. More research is required to consider an activity of elements of European, American, and Asian insurance market infrastructure as leading in the world.

\section{References:}

Ermolaev, G.B. (2011). Information transparency and its impact on the development of the insurance market infrastructure. Stage: economic theory, analysis, practice, Vol. 6, p. 132-141.

Lee, R. (2011). Running the World's Markets: The Governance of Financial Infrastructure. Princeton: Princeton University Press, $472 \mathrm{p}$.

Rotova, T.A. and Zaychuk, S.V. (2014). Infrastructure features of the market of health insurance services. Ekonomichnyi visnyk universytetu, Vol. 23/1, p. 239-244.

Vasiliev, O.V. (2013). Problems of improvement of the infrastructure of insurance market. Visnyk Chernihivskoho derzhavnoho tekhnolohichnoho universytetu, Vol. 2 (66), p. 204-208.

www.iaisweb.org. (2017). Iaisweb.org. Retrieved 31 October 2017, from https://www.iaisweb.org/page/aboutthe-iai

www.naic.org. (2017). Naic.org. Retrieved 31 October 2017, from http://www.naic.org/store/free/FRD-OP.pdf GFIA/About us / Overview. (2017). Gfiainsurance.org. Retrieved31 October 2017,from http://gfiainsurance.org/ en/About-us/Overview/

About International Insurance Foundation. (2017). Iifdc.org. Retrieved 31 October 2017, from https://iifdc.org/?page_id=59

About IADI. (2017). iadi.org. Retrieved 31 October 2017, from http://www.iadi.org/en/about-iadi/organisation/ About The Berne Union. (2017). berneunion.org. Retrieved 31 October 2017, from https://www.berneunion. org/Stub/Display/8

About us / AIAG. (2017). Aiag-iahi.org. Retrieved 31 October 2017, from http://www.aiag-iahi.org/en/about-us/ About the Group. (2017). Igpandi.org. Retrieved 31 October 2017, from https://www.igpandi.org/about

About us. (2017). Iuai.org. Retrieved 31 October 2017, from https://iuai.org/IUAI/About/Public/About/About. aspx?hkey=d8d8da15-56bb-4d94-8689-e2a2803d706d

Introducing IUMI. (2017). Iumi.com. Retrieved 31 October 2017, from https://iumi.com/about/introducingiumi

The Organisation. (2017). Imia.com. Retrieved 31 October 2017, from https://www.imia.com/the-organisation/ International Association of Insurance Professionals. (2017). Internationalinsuranceprofessionals.org. Retrieved 31 October 2017, from http://www.internationalinsuranceprofessionals.org/

ABOUT - INDEX (EN). (2017). Actuaries.org. Retrieved 31 October 2017, from http://www.actuaries.org/ index.cfm $? \mathrm{LANG}=\mathrm{EN} \& \mathrm{DSP}=\mathrm{ABOUT} \& \mathrm{ACT}=\mathrm{INDEX}$

About us / AMD Adjusters / Association Mondiale de Dispacheurs / International Association of Average Adjusters. (2017). Amdadjusters.org. Retrieved 31 October 2017, from http://amdadjusters.org/bringingsolutions-to-problems

Swiss Re (2013). World Insurance in 2012: Progressing on the long and winding road to recovery, Sigma, No. 3, Zurich, Switzerland. Retrieved from http://media.swissre.com/documents/sigma3_2013_en.pdf

Swiss Re (2014). World Insurance in 2013: Steering towards recovery, Sigma, No. 3, Zurich, Switzerland. Retrieved from http://media.swissre.com/documents/sigma3_2014_en.pdf

Swiss Re (2015). World Insurance in 2014: Back to life, Sigma, No. 4, Zurich, Switzerland. Retrieved from http://media.swissre.com/documents/sigma4_2015_en.pdf

Swiss Re (2016). World Insurance in 2015: Steady growth amid regional disparities, No. 3, Zurich, Switzerland. Retrieved from http://media.swissre.com/documents/sigma_3_2016_en.pdf

Swiss Re (2017). World Insurance in 2016: the China growth engine steams ahead, No. 3, Zurich, Switzerland. Retrieved from http://media.swissre.com/documents/sigma3_2017_en.pdf 


\section{Антонина ШолоЙКо}

\section{РОЛЬ ИНФРАСТРУКТУРЫ МИРОВОГО СТРАХОВОГО РЫНКА}

Аннотация. Целью работы является определение роли и значения элементов инфраструктуры мирового страхового рынка. Для достижения цели были поставлены следующие задачи: рассмотреть динамику развития мирового страхового рынка с 2012 по 2016 гг.; определить группы элементов инфраструктуры мирового страхового рынка; охарактеризовать элементы инфраструктуры мирового страхового рынка. Методология. Поставленные задачи были выполнены через использование таких методов, как: группировка элементов инфраструктуры мирового страхового рынка, сбор информации о элементах инфраструктуры мирового страхового рынка, обобщение для определения роли и значения элементов инфраструктуры мирового страхового рынка. Результаты. Мировые страховые премии увеличивались и снижались с 2012 по 2016 гг. и не превышали 6,3\% в валовом внутреннем продукте. На объем мировых страховых премий как показатель развития мирового страхового рынка влияет множество факторов. Одним из них является деятельность элементов инфраструктуры мирового страхового рынка, которые необходимо поделить на несколько групп: А) Международные страховые ассоциации (ассоциации организаций, связанных со страхованием, но члены таких ассоциаций не предоставляют страховые услуги - Международная ассоциация органов страхового надзора, Международная ассоциация агентств по борьбе со страховым мошенничеством, Глобальная федерация страховых ассоциаций, Международный страховой фонд); В) Международные ассоциации страховщиков (ассоциации страховщиков и других организаций из определенной области страхования - Международная ассоциация страховщиков депозитов, Международный союз страховщиков кредитов и инвестиций, Международная ассоциация страховщиков сельскохозяйственного производства, Международная группа клубов P\&l, Международный союз авиакосмических страховщиков, Международный союз морского страхования, Международная ассоциация страховщиков технических рисков); С) Международные ассоциации экспертов в сфере страхования (ассоциация страховых экспертов, которые обслуживают предоставление страховых услуг - Международная ассоциация профессионалов по страхованию, Международная организация актуариев, Международная ассоциация аджастеров). Значение. Это исследование показало, что все группы элементов инфраструктуры мирового страхового рынка играют значительную роль в развитии страховой отрасли, поскольку они ставят перед собой такие задачи, как: обеспечение глобальной стабильности, безопасности и эффективности посредством сотрудничества с национальными правительствами и предоставления членам ассоциаций информации, образования, консультаций и других услуг. Необходимо также провести дополнительные исследования, чтобы рассмотреть деятельность элементов инфраструктуры европейского, американского и азиатского страховых рынков как ведущих в мире. 